\title{
Pharmacological Therapy in Panic Disorder: Current Guidelines and Novel Drugs Discovery for Treatment-resistant Patient
}

\author{
Mohamed S. Zulfarina', Syed-Badrul Syarifah-Noratiqah ${ }^{1}$, Shuid A. Nazrun', Razinah Sharif ${ }^{2}$, \\ Isa Naina-Mohamed ${ }^{\mathbf{1}}$ \\ ${ }^{1}$ Pharmacoepidemiology and Drug Safety Unit, Department of Pharmacology, Faculty of Medicine, Universiti Kebangsaan Malaysia Medical \\ Centre, ${ }^{2}$ Program of Nutritional Sciences, Faculty of Health Sciences, Universiti Kebangsaan Malaysia, Kuala Lumpur, Malaysia
}

\begin{abstract}
Panic disorder (PD) being one of the most intensively investigated anxiety disorders is considered a heterogeneous psychiatric disease which has difficulties with early diagnosis. The disorder is recurrent and usually associated with low remission rates and high rates of relapse which may exacerbated social and quality of life, causes unnecessary cost and increased risk for complication and suicide. Current pharmacotherapy for PD are available but these drugs have slow therapeutic onset, several side effects and most patients do not fully respond to these standard pharmacological treatments. Ongoing investigations indicate the need for new and promising agents for the treatment of PD. This article will cover the importance of immediate and proper treatment, the gap in the current management of PD with special emphasis on pharmacotherapy, and evidence regarding the novel anti-panic drugs including the drugs in developments such as metabotropic glutamate (mGlu 2/3) agonist and levetiracetam. Preliminary results suggest the anti-panic properties and the efficacy of duloxetine, reboxetine, mirtazapine, nefazodone, risperidone and inositol as a monotherapy drug. Apart for their effectiveness, the aforementioned compounds were generally well tolerated compared to the standard available pharmacotherapy drugs, indicating their potential therapeutic usefulness for ambivalent and hypervigilance patient. Further strong clinical trials will provide an ample support to these novel compounds as an alternative monotherapy for PD treatment-resistant patient.
\end{abstract}

KEY WORDS: Antipsychotic agents; Antidepressive agents; Panic attack; Treatment-resistant; Clinical trial.

\section{INTRODUCTION}

Panic disorder (PD) being one of the most intensively investigated anxiety disorders, is among the most common mental disorders affecting $2.7 \%$ of the population per year with a lifetime prevalence rate of up to $5 \%$ in the general population $^{1,2)}$ and as high as $10 \%$ in the medical setting. ${ }^{3)} \mathrm{PD}$ is twice more often to occur in women than in men and usually develop in late adolescence or early adulthood, with an average age onset of 28 year old. ${ }^{1,4}$ Approximately $10 \%$ of children and adolescents are diag-

Received: August 3, 2018 / Revised: October 11, 2018

Accepted: October 12, 2018

Address for correspondence: Isa Naina-Mohamed, MD, PhD Pharmacoepidemiology and Drug Safety Unit, Department of Pharmacology, Faculty of Medicine, Universiti Kebangsaan Malaysia Medical Centre, 56000 Cheras, Kuala Lumpur, Malaysia Tel: +60-03-91459545, Fax: +60-03-91459547

E-mail: isanaina@ppukm.ukm.edu.my

ORCID: https://orcid.org/0000-0001-8891-2423 nosed with PD.

Conforming to the Diagnostic and Statistical Manual of Mental Disorders 4th edition, text revision (DSM-IV-TR), $\mathrm{PD}$ is defined as the presence of recurrent unexpected panic attack followed by at least one month of persistent concern about having additional attacks, worry about the implications of the attack or its consequences and a significant change in behavior related to the panic attacks. Moreover, the conditions of the panic attacks should not due to the direct effect of a substance or medical condition and are not better accounted for by another mental disorder. The panic attack itself according to DSM-IV-TR ${ }^{6)}$ is interpreted by a discrete period of intense fear or discomfort in which at least four of the following symptoms develop abruptly and builds to a peak rapidly within 10 minutes. For ease of interpretation, the symptoms can be classified to two systems; first, the somatic systems such as palpitations, pounding heart or accelerated heart rate,

(ㄷ) This is an Open-Access article distributed under the terms of the Creative Commons Attribution Non-Commercial License (http://creativecommons.org/licenses/by-nc/4.0) which permits unrestricted non-commercial use, distribution, and reproduction in any medium, provided the original work is properly cited. 
sweating, trembling or shaking, sensation of breathlessness or smothering, choking sensation, chest pain or discomfort, nausea or abdominal distress, faintness or dizziness and chills or hot flushes. Second, cognitive system such as derealization (feeling of unreality) or depersonalization (being detached from oneself), going mad or loss of control, fear of dying and paresthesia (numbness or tingling sensation). About one-fourth of people suffering from PD also have agoraphobia." In PD, patients are known to suffer from agoraphobia when they are extremely anxious about being in places or other situations from which escape might be difficult or in which help would not be available if they have panic attack or panic-like symptoms. The anxiety typically develops to a pervasive avoidance of a range of situation that may include scared of being outside the home unaccompanied or in crowd or home alone, travelling by car, bus or airplane or on a bridge or in an elevator. ${ }^{6)}$

Understanding the cause of PD might open the possibility of early detection and new treatment era. However, the exact pathophysiology of PD is very much a grey area but psychobiological causation is the current suggested mechanism. The proposed neuroanatomic model suggest that panic attacks occur in subjects with dysfunctional fear network, including amygdala and its connection with the hypothalamus, hippocampus, thalamus, periaqueductal grey region, locus coeruleus and prefrontal cortex. The inappropriate activation of amygdala then stimulates neuroendocrine, autonomic and behavioral responses to fear or stress. ${ }^{8)}$ Different neurotransmitter such as serotonin, norepinephrine, and $\gamma$-aminobutyric acid (GABA) acting in different brain areas and influencing each other may be involved in modulating these processes. To date, the mechanisms of existing anti-panic drugs are not fully understood ${ }^{9,10)}$ but these drugs probably act in the amygdala and its projection via reducing the fear network sensitivity and subsequently lowering the severity and frequency of panic attacks. ${ }^{11,12)}$ Others postulate that PD represents a state of instability of respiratory regulation and hypersensitivity of central neural network of carbon dioxide/hydrogen ions $\left(\mathrm{CO}^{2} / \mathrm{H}^{+}\right)$chemoreception, which has been implicated both in experimentally evoked panic attacks via carbon dioxide inhalation, sodium lactate infusion and in spontaneous panic attack. ${ }^{13,14)}$

In addition to the unknown etiology, PD is considered a heterogeneous psychiatric disease which has difficulties with early diagnosis. PD usually comorbid with other medical conditions such as respiratory or cardiac diseases, other mental disorders such as psychoactive substance abuse including alcohol, caffeine, cannabis and cocaine, affective disorder, anxiety disorder including post-traumatic stress disorder (PTSD), obsessive-compulsive disorder and social phobia. ${ }^{15,16)}$ Panic attack can also occur in other psychiatric disorder. However, panic attacks in other disorders are predictable and related to the avoidance of specific situation that can trigger stimuli to the subjects such as being in a crowd in patients suffering from social phobia and situations that refer to a traumatic event in patients suffering from PTSD. ${ }^{17)}$

The course of PD is variable, and in many cases PD may be chronic or recurrent and when severe can be a debilitating disease associated with low remission rates and high rates of rebound. Since PD is associated with medical comorbidity or psychiatric complication, most PD patients require continuous or intermittent treatment to achieve remission or prevent relapse. In view of all that has been mentioned thus far, PD is associated with significant impairment in quality of life and social functioning and has high suicide tendencies. ${ }^{18)}$ PD as compared to healthy individuals and to other psychiatric disorders causes enormous economic burden for the health care system as well as to the society. ${ }^{19)}$ People with panic attacks often show high unemployment rates, have significant work impairment ${ }^{20)}$ and typically present to general practitioners or to a range of medical specialists seeking treatment for their medically unexplained symptoms. ${ }^{21)}$ The overuse of medical services among PD patients are probably because PD mimics many medical conditions or is often associated with cognitive misinterpretation of physical sensations. ${ }^{4,18)}$ Due to the severity and serious characteristics of this disorder, early identification (albeit it is not simple) is essential and having a proper treatment is a top priority so that functioning and quality of life can be improved and unnecessary medical costs and risk of complications can be avoided. ${ }^{22)}$

\section{CLINICAL GUIDELINES AND EVIDENCE BASE}

According to the National Institute for Health and Clinical Excellence (NICE) guidelines, the best treatment 
options for PD were cognitive behavioral therapy (CBT), pharmacological interventions with antidepressants, and self-help. ${ }^{23)}$ The recommendation is in agreement with one meta-analysis comparing the efficacy of CBT, pharmacotherapy and placebo in PD. Both pharmacotherapy and CBT were found to be superior to placebo and neither treatment showed superior efficacy compared to each other. $^{24)}$ In addition to the meta-analysis mentioned above, a recent meta-analysis ${ }^{25)}$ also found similar efficacy between the pharmacotherapy and CBT.

Concerning the pharmacological interventions, licensed selective serotonin reuptake inhibitors (SSRIs) are considered as first choice pharmacological treatment, but tricyclic antidepressants (TCAs) could also be prescribed. According to the NICE guidelines, benzodiazepines should not be prescribed because they are associated with less favorable outcome in the long term plus the effectiveness of serotonin and norepinephrine reuptake inhibitors (SNRIs) venlaflaxine was not acknowledged. ${ }^{23)}$ However, a number of meta-analysis have demonstrated similar efficacy between antidepressants and benzodiazepines, ${ }^{26,27)}$ between SSRIs and TCAs, ${ }^{27-29)}$ between benzodiazepines, SSRIs and TCAs, ${ }^{23)}$ though benzodiazepines have better tolerability than antidepressants ${ }^{26,27)}$ while SSRIs have better tolerability than TCAs. ${ }^{27,29)}$ Several recent studies also demonstrated evidence that SNRI venlaflaxine is an effective treatment for $\mathrm{PD},{ }^{9,30)}$ and should perhaps warrant an appraisal of the current NICE guideline to include SNRIs and benzodiazepines as standard treatment for PD.

The American Psychiatric Association (APA) guidelines recommended pharmacotherapy or CBT and SSRIs, SNRIs, TCAs, and benzodiazepines because current evidence is not enough to ascertain which of these treatment modalities is superior for all patients. ${ }^{31)}$ On the other hand, the World Federation of Societies of Biological Psychiatry (WFSBP) guidelines recommended the SSRIs (citalopram, escitalopram, fluoxetine, sertraline, fluvoxamine, paroxetine) and the SNRI venlafaxine as the first-line treatment for PD, while the TCAs (imipramine and clomipramine), the benzodiazepines (alprazolam, clonazepam, lorazepam and diazepam) and the monoamine oxidase inhibitors (MAOI) phenelzine were considered as a second-line treatment owing to their associated side effects profile. ${ }^{32)}$

To date, the available pharmacological treatments for PD with strong evidence from clinical trials to support their efficiency are antidepressants (SSRIs [citalopram, escitalopram, fluoxetine, sertraline, fluvoxamine, paroxetine], SNRIs [venlaflaxine], TCAs [imipramine and clomipramine], MAOI [phenelzine]) and benzodiazepines (alprazolam, clonazepam, lorazepam and diazepam). ${ }^{19,33)}$ A recent systematic review concluded that, antidepressants as a whole, SSRIs, TCAs and benzodiazepines have similar efficacies and benzodiazepines have best tolerability, followed by SSRIs. ${ }^{27)}$ Based on the mechanism of action, SNRIs, some TCAs and MAOI modulate both the serotonergic and noradrenergic systems, whereas SSRIs and norepinephrine reuptake inhibitor (NRI) regulate only the serotonergic or noradrenergic activities respectively. Benzodiazepines on the other hand may have act via the inhibition of the GABA receptors. ${ }^{34)}$

During initial treatment, the standard available pharmacotherapy (SSRIs, SNRIs and TCAs) has a slow onset of therapeutic action (4-10 weeks) and often require combination therapy with benzodiazepines. Albeit benzodiazepines have fast anxiolytic effects property, yet it is associated with potential side effects profile including sedation, cognitive impairment, risk of tolerance and dependence. $^{35)}$

Furthermore, patients treated with SSRIs, SNRIs and TCAs often have an initial increase in anxiety (jittering syndrome). Patients with this body hypervigilance (misinterpreting physical side-effects as panic attack symptoms) may cause significant tolerability issues before experiencing the significant benefits of pharmacotherapy and possibly may cease the medication. ${ }^{22)}$ Among these three drugs, the second generation antidepressant SSRIs and SNRI are better tolerated than the first generation antidepressant TCAs. However, SSRIs and SNRI treatments can cause unwanted side effects including sexual dysfunctions and weight gain. ${ }^{36,37)}$

As large as $45 \%$ of patients do not fully respond to standard first-line therapy or failed to achieve a full and stable remission $^{4,18,28)}$ although recommended medications are used and the doses and the length of treatment are adequate. $^{10)}$ On top of that, between $25 \%$ and $50 \%$ of patients relapse within 6 months after medical drug taper and up to $50 \%$ still experience residual PD symptoms and up to $30 \%$ of patients still suffer from a full-blown PD after 3 to 6 years. $^{38)}$

In practice, those PD patients who do not fully respond to an adequate treatment of two SSRI, venlaflaxine ex- 
tended release, one of TCAs, benzodiazepines, or combination of any antidepressants with benzodiazepines can be considered as treatment-resistant to pharmacotherapy. A possible explanation for this could be due to low efficacy of standard pharmacological treatments, unable to tolerate some of these drugs or if some medications could not be prescribed to them. ${ }^{22)}$

Despite all these established pharmacological options, there is still a demand for more effective, less side effect/better tolerance, faster onset of therapeutic action and acute anxiolytic activity with the outcome of the therapy should include a full and sustained remission of all PD symptoms including its comorbid disease. Accordingly, this article aims to review promising monotherapies of novel pharmacological agents including two novel compounds in development with clinical potential for the treatment of PD.

\section{A NEW HOPE FOR PD TREATMENT-RESISTANT PATIENTS}

\section{Novel Drug Discovery}

There are evidences indicating new compounds have an anti-panic properties and may be effective for the treatment of PD. ${ }^{9,10,34)}$ These new compounds are novel antidepressants such as duloxetine, reboxetine, mirtazapine, nefazodone and other novel therapeutic agents such as atypical antipsychotic-risperidone, and inositol. It is worth mentioning that currently, these novel compounds are not recommended for standard treatment but could be considered as an alternative monotherapy for treatment-resistant patients with PD. ${ }^{4,10)}$ Table 1 summarizes the evidence for the new anti-panic drugs in the treatment of PD. Figure 1 illustrate the mechanism of action at the neurotransmitter-receptor for selected novel anti-panic drugs.

Table 1. Potential anti-panic drugs for the treatment of panic disorder

\begin{tabular}{|c|c|c|c|c|c|}
\hline $\begin{array}{c}\text { Classification of } \\
\text { pharmacological } \\
\text { classes }\end{array}$ & $\begin{array}{l}\text { Drug \& dosage } \\
\text { (mg/day) }\end{array}$ & $\begin{array}{l}\text { Comparing drug \& } \\
\text { dosage (mg/day) }\end{array}$ & Study type & $\begin{array}{l}\text { Major } \\
\text { finding }\end{array}$ & Reference \\
\hline SNRI & Duloxetine (60-120) & - & Non-controlled & Effective & Simon et al., 2009 \\
\hline NaSSA & Mirtazapine (15-30) & - & Non-controlled & Effective & Carpenter et al., 1999 \\
\hline NaSSA & Mirtazapine (30-45) & - & Non-controlled & Effective & Boshuisen et al., 2001 ${ }^{43)}$ \\
\hline NaSSA & Mirtazapine (13-30) & $\begin{array}{l}\text { Fluoxetine } \\
(10-20)\end{array}$ & $\begin{array}{l}\text { Double-blind, randomized, } \\
\text { controlled }\end{array}$ & $\begin{array}{l}\text { Mirtazapine= } \\
\text { fluoxetine }\end{array}$ & Ribeiro et al., 2001 ${ }^{46)}$ \\
\hline NaSSA & Mirtazapine (30) & - & Non-controlled & Effective & Carli et al., 2002 $2^{44)}$ \\
\hline NaSSA & Mirtazapine (30) & - & Non-controlled & Effective & Sarchiapone et al., 2003 ${ }^{45)}$ \\
\hline NaSSA & Mirtazapine (30) & $\begin{array}{l}\text { Paroxetine } \\
(20-30)\end{array}$ & Nonrandomized, controlled & $\begin{array}{l}\text { Mirtazapine= } \\
\text { paroxetine }\end{array}$ & $\begin{array}{l}\text { Montañes-Rada } \\
\text { et al., 2005 }\end{array}$ \\
\hline NRI & Reboxetine (2-8) & - & Non-controlled & Effective & Dannon et al., 2002 ${ }^{49)}$ \\
\hline NRI & Reboxetine (6-8) & - & $\begin{array}{l}\text { Double-blind, randomized, } \\
\text { placebo-controlled }\end{array}$ & $\begin{array}{l}\text { Reboxetine }> \\
\text { placebo }\end{array}$ & Versiani et al., 2002 $2^{50)}$ \\
\hline NRI & Reboxetine (6-8) & $\begin{array}{l}\text { Citalopram } \\
(20-60)\end{array}$ & $\begin{array}{l}\text { Single-blind, randomized, } \\
\text { controlled, crossover }\end{array}$ & $\begin{array}{l}\text { Reboxetine= } \\
\text { citalopram }\end{array}$ & Seedat et al., 2003 ${ }^{51)}$ \\
\hline NRI & Reboxetine (8) & Paroxetine (40) & $\begin{array}{l}\text { Single-blind, randomized, } \\
\text { controlled }\end{array}$ & $\begin{array}{c}\text { Paroxetine }> \\
\text { reboxetine }\end{array}$ & Bertani et al., 2004 \\
\hline SARI & Nefazodone (200-600) & - & Non-controlled & Effective & DeMartinis et al., $1996^{54)}$ \\
\hline SARI & Nefazodone (50-400) & - & Non-controlled & Effective & Bystritsky et al., 1999 \\
\hline SARI & Nefazodone (100-300) & - & Non-controlled & Effective & Papp et al., 2000 \\
\hline $\begin{array}{l}\text { Atypical } \\
\text { antipsychotic }\end{array}$ & $\begin{array}{r}\text { Risperidone } \\
(0.125-1.0)\end{array}$ & $\begin{array}{l}\text { Paroxetine } \\
(30-40)\end{array}$ & $\begin{array}{l}\text { Single-blind, randomized, } \\
\text { controlled }\end{array}$ & $\begin{array}{l}\text { Risperidone }= \\
\text { paroxetine }\end{array}$ & Prosser et al., 2009 \\
\hline $\begin{array}{l}\text { Inositol } \\
\text { systemic }\end{array}$ & Inositol (12 g) & - & $\begin{array}{l}\text { Double-blind, randomized, } \\
\text { placebo-controlled, crossover }\end{array}$ & $\begin{array}{r}\text { Inositol }> \\
\text { placebo }\end{array}$ & Benjamin et al., $1995^{60)}$ \\
\hline $\begin{array}{l}\text { Inositol } \\
\text { systemic }\end{array}$ & Inositol (18 g) & $\begin{array}{l}\text { Fluvoxamine } \\
\text { (150) }\end{array}$ & $\begin{array}{l}\text { Double-blind, randomized } \\
\text { controlled, crossover }\end{array}$ & $\begin{array}{l}\text { Inositol= } \\
\text { fluvoxamine }\end{array}$ & Palatnik et al., 2001 ${ }^{61)}$ \\
\hline
\end{tabular}

SNRI, serotonin norepinephrine reuptake inhibitors; NaSSA, noradrenergic and specific serotonergic antidepressant; NRI, norepinephrine reuptake inhibitors; SARI, serotonin antagonist and reuptake inhibitors; $=$, equal efficiency; $>$, superior than. 


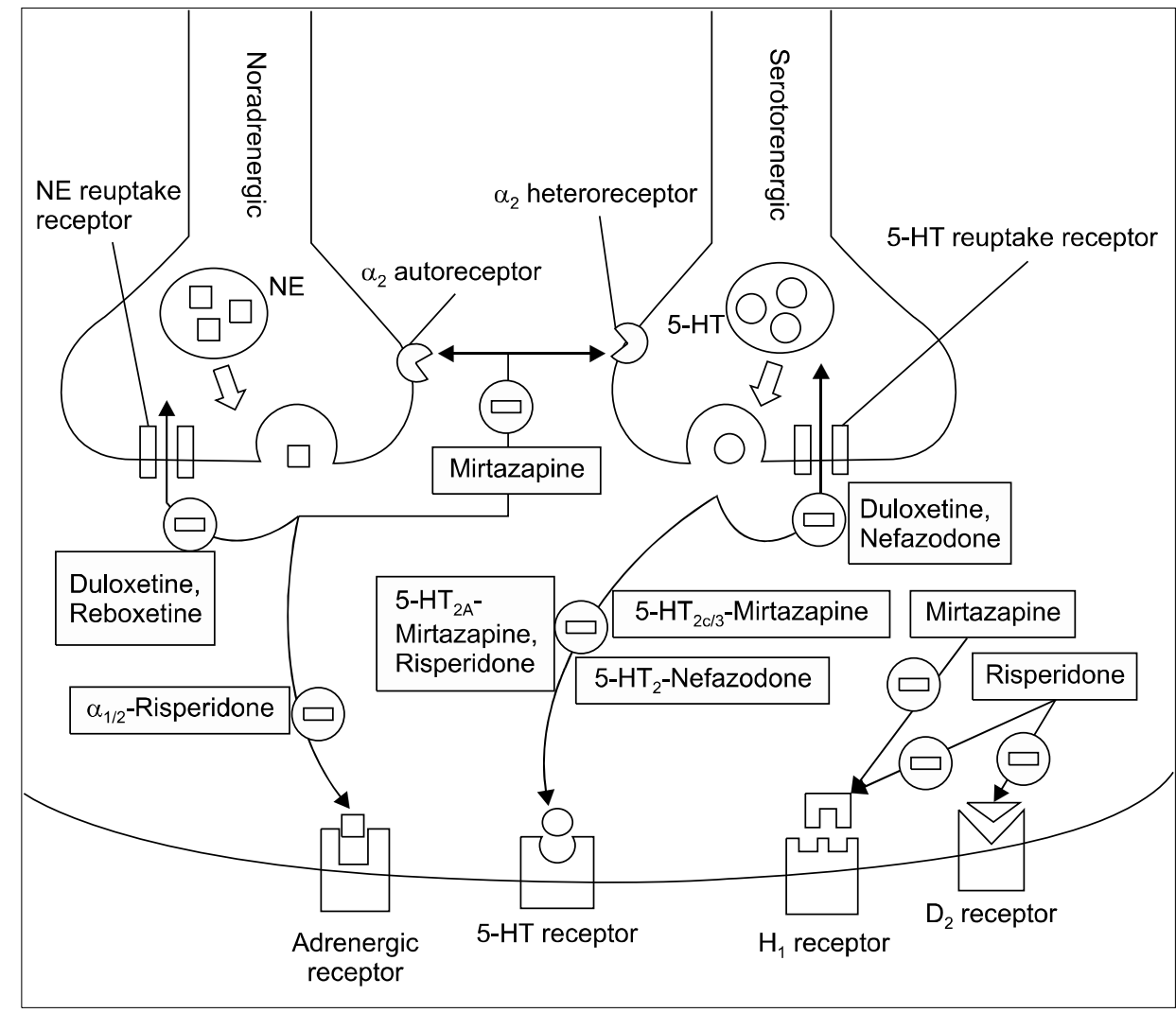

Fig. 1. Mechanism of action of novel anti-panic drugs at the synapse of the brain neuron. 1. Mirtazapine, nefazodone, risperidone inhibits postsynaptic receptors and prevent postsynaptic response. 2. Mirtazapine inhibit auto/heteroreceptor at the presynaptic neuron and promote subsequent neurotransmitter release. 3. Duloxetine, reboxetine, nefazodone inhibits the reuptake transporter to prevent neurotransmitter reuptake into the presynaptic neuron.

$\mathrm{NE}$, norepinephrine; $5-\mathrm{HT}$, serotonin; $\mathrm{D}_{2}$, dopamine $2 ; \mathrm{H}_{1}$, histamine 1 .

\section{Duloxetine}

Duloxetine is a potent dual SNRI that lacks of affinity for histamine $H 1$, adrenergic $\alpha 1$, dopamine $D_{2}$, serotonin $5-\mathrm{HT}_{1} \mathrm{~A} / 5-\mathrm{HT}_{1} \mathrm{~B} / 5-\mathrm{HT}_{1} \mathrm{D}, 5 \mathrm{HT}_{2} \mathrm{~A} / 5 \mathrm{HT}_{2} \mathrm{C}$ and opioid receptors. ${ }^{39)}$ In a single open label trial, duloxetine was significantly effective in improving panic and other severity symptoms in PD patients with or without comorbidity, and also in patient with refractory PD. Duloxetine was well tolerated with only two study discontinuations. ${ }^{40)}$ In future, further large randomized controlled studies testing the utility of duloxetine is necessary.

\section{Mirtazapine}

Mirtazapine is an atypical noradrenergic and specific serotonergic antidepressant (NaSSA). It has dual mode of action because it enhances norepinephrine neurotransmission via antagonizing the adrenergic $\alpha_{2}$-autoreceptors and $\alpha_{2}$-heteroceptors at presynaptic sites as well as serotonergic $5-\mathrm{HT}_{1} \mathrm{~A}$ neurotransmission via antagonizing the serotonergic 5- $\mathrm{HT}_{2 / 3}$ receptor postsynaptic sites. ${ }^{41)}$ Good response rates and significant symptomatic improvements were found in all four open trials of treatment with mirta- zapine in PD patients. ${ }^{42-45)}$ The subsequent two comparative studies found that mirtazapine was equally effective to fluoxetine ${ }^{46)}$ and paroxetine ${ }^{47)}$ in reducing panic symptoms. Mirtazapine was well tolerated with the most frequent side effect reported was weight gain. ${ }^{42,43,46)}$ These studies however have methodological shortcomings including the frequent use of concomitant drugs (benzodiazepines), small sample size which may not detect small statistical differences between mirtazapine and active comparators and the absence of a placebo control group. Well-designed clinical trial in the future will provide a concrete evidence for mirtazapine as a monotherapy agent for PD.

\section{Reboxetine}

Reboxetine is a selective and specific NRI which has low affinity for muscarinic, histaminergic $\mathrm{H} 1$, dopaminergic $D_{2}$ and adrenergic $\alpha_{1}$ receptors. ${ }^{48)}$ A significant reduction in panic symptoms observed suggested a possible efficacy of reboxetine in previous noncompliance treatment of SSRI and in patients without comorbid agoraphobia. $^{49)}$ In the first randomized placebo-con- 
trolled trial, reboxetine was superior to placebo in the treatment of $\mathrm{PD}{ }^{50)}$ Further randomized crossover study found that reboxetine was equally effective as citalopram in alleviating the severity of panic attacks. ${ }^{51)}$ Another trial found that reboxetine was not as effective as paroxetine in reducing reactivity to $35 \%$ carbon dioxide/ $65 \%$ oxygen inhalation. ${ }^{52)}$ Despite the fact that reboxetine showed inferior efficacy than paroxetine in the treatment of PD, reboxetine might offer some advantageous since sexual dysfunction or weight gain associated with SSRIs was not found in patients receiving reboxetine and possibly suggesting higher clinical importance of regulating the serotonergic system than the noradrenergic system alone in PD patients. ${ }^{10,33)}$

\section{Nefazodone}

Nefazodone is a combined serotonin $\left(5-\mathrm{HT}_{2} \mathrm{~A}\right)$ receptor antagonists and serotonin reuptake inhibitor (SARI). Nefazodone has the ability to inhibit serotonin reuptake presynaptically and serotonin $5-\mathrm{HT}_{2} \mathrm{~A}$ receptors postsynaptically, while indirectly stimulates the serotonin 5- $\mathrm{HT}_{1} \mathrm{~A}$ receptor. ${ }^{53)}$ Thus far, the efficacy of nefazodone was tested in three open-label trials. ${ }^{54-56)}$ The results from all the three open label studies indicate that nefazodone was significantly effective in improving severity scores and was well tolerated in the treatment of PD thus justifying for further large randomized controlled studies.

\section{Risperidone}

Risperidone is a new atypical antipsychotic agent and potent antagonist of serotonin $5-\mathrm{HT}_{2} \mathrm{~A}$ and dopamine $\mathrm{D}_{2}$ receptors. ${ }^{57)}$ In one single-blind randomized controlledtrial, low-dose of risperidone and paroxetine showed equal efficacy and tolerability in reducing the frequency and severity of panic attacks. Furthermore, patients receiving risperidone may have faster clinical response than patients receiving paroxetine. ${ }^{58)}$ This preliminary result suggested that low-dose of risperidone may provide an effective relief but further large controlled studies are crucial to confirm this result.

\section{Inositol}

Inositol or myo-inositol is a simple isomer of glucose and an important precursor in the phosphatidylinositol (PI-cycle) second messenger system in the brain. ${ }^{59)}$ In a double-blind randomized study, inositol showed a higher efficiency than placebo with no substantial side effects reported. ${ }^{60)}$ In a further randomized crossover trial comparing inositol with fluvoxamine, symptomatic improvements were similar for both treatments although frequent side effects of nausea and tiredness were reported in patients receiving fluvoxamine. ${ }^{61)}$ The second-messenger strategy as opposed to the transmitter-receptor strategy is a novel therapeutic mechanism for PD and deserves further investigation.

\section{Emerging Compounds}

Two new compounds with clinical potential for future developments are reviewed in this section. Table 2 summarizes the evidence for emerging compounds in PD.

Table 2. Novel compounds in development for the treatment of panic disorder (PD)

\begin{tabular}{|c|c|c|c|c|c|c|}
\hline Novel drug & $\begin{array}{l}\text { Dosage } \\
\text { (mg/day) }\end{array}$ & $\begin{array}{l}\text { Experimental } \\
\text { method }\end{array}$ & $\begin{array}{l}\text { Study design (type of study, } \\
\text { sample size, duration of study) }\end{array}$ & $\begin{array}{l}\text { Mechanism } \\
\text { of action }\end{array}$ & Major finding & $\begin{array}{l}\text { Reference } \\
\text { (trial) }\end{array}$ \\
\hline $\begin{array}{l}\text { Eglumegad or } \\
\text { LY354740 }\end{array}$ & $\begin{array}{l}\text { 200, twice } \\
\text { daily }\end{array}$ & $\begin{array}{l}\text { Single breath of } \\
35 \% \mathrm{CO}_{2} / 65 \% \\
\mathrm{O}_{2} \text { mixture }\end{array}$ & $\begin{array}{l}\text { Double-blind, randomized } \\
\text { placebo controlled ( } 4 \mathrm{wk} \text {, } \\
30 \text { PD patients) }\end{array}$ & mGluR2/3 & LY354740 > placebo & $\begin{array}{l}\text { Schoepp et al., } \\
2003^{5)}\end{array}$ \\
\hline $\begin{array}{l}\text { Eglumegad or } \\
\text { LY354740 }\end{array}$ & $\begin{array}{l}100 \text { or } 200 \\
\text { paroxetine } \\
60\end{array}$ & - & $\begin{array}{l}\text { Double-blind, randomized } \\
\text { placebo controlled ( } 9 \mathrm{wk} \text {, } \\
37 \text { PD patients) }\end{array}$ & mGluR2/3 & $\begin{array}{l}\text { LY354740=paroxetine } \\
=\text { placebo }\end{array}$ & $\begin{array}{l}\text { Bergink et al., } \\
2005^{66)}\end{array}$ \\
\hline LY544344 & 80 & $\begin{array}{l}\text { Intravenous } \\
\text { injection of } 50 \\
\mu \mathrm{g} \text { CCK-4 }\end{array}$ & $\begin{array}{l}\text { Double-blind, randomized, } \\
\text { placebo controlled, } \\
\text { cross-over ( } 1 \mathrm{wk}, 12 \\
\text { healthy human) }\end{array}$ & mGluR2/3 & LY544344 > placebo & $\begin{array}{l}\text { Kellner et al., } \\
2005^{68)}\end{array}$ \\
\hline Levetiracetam & $\begin{array}{l}\text { 250, twice } \\
\text { daily }\end{array}$ & - & $\begin{array}{l}\text { Non-controlled ( } 12 \mathrm{wk}, 18 \\
\text { PD patients) }\end{array}$ & $\begin{array}{l}\text { Synaptic } \\
\text { vesicle } \\
\text { protein 2A }\end{array}$ & Effective & Papp, $2006^{72)}$ \\
\hline
\end{tabular}

mGluR2/3, type II metabotropic glutamate receptors; CCK-4, cholecystokinin tetrapeptide; =, equal efficiency; $>$, superior than. 
Eglumegad or metabotropic glutamate (mGlu 2/3) receptors agonist

Eglumegad is a selective type II mGlu $2 / 3$ receptors agonist. Type II mGlu 2/3 receptor agonist reduce glutamate neurotransmission at presynaptic sites (as inhibitory auto-receptors) and postsynaptic sites (as hetero-receptors) to control the release of GABA and other neurotransmitters. ${ }^{62,63)}$ The anti-panic effects of group II metabotropic glutamate receptors (mGluR2/3) agonist such as LY354740 have been studied in lactate-induced (NaLac) panic-like response in panic-prone rat model where the systemic injection of LY354740 was equally efficient as alprazolam in preventing NaLac-induced panic-like response. Furthermore, the utility of LY354740 is not hindered by sedation which is one of the major side effects of benzodiazepines. ${ }^{62)}$ In addition, the anxiolytic profile displayed in panic-prone rats is similar to those showed in the fear-potentiated startle paradigm in human. ${ }^{64)}$ Thus, type II mGlu 2/3 receptors agonist may have the potential clinical utilities with novel mechanism and favorable side effects.

A randomized, double blind, placebo controlled study has been conducted to investigate the effect and safety of LY354740 in PD patients. This study indicate that LY354740 was more efficacious in alleviating panic symptoms after 4 weeks of treatment and greater clinical improvement for 3 of the 4 treatment weeks than those receiving placebo. In addition, LY354740 reported no significant adverse effects compared to placebo. ${ }^{65)}$ Following the promising result from the Phase I trial, another randomized double-blind placebo-controlled trial was conducted. PD patients were given either LY354740 (100 or $200 \mathrm{mg})$, paroxetine $(60 \mathrm{mg})$ as an active comparator or placebo for 9 weeks. LY354740 was well tolerated. However, results failed to reach statistical significant difference as compared to placebo. ${ }^{66)}$

Therefore, a dipeptide prodrug LY544344, the prodrug of LY354740 has been developed to enhance the absorption and bioavailability of LY354740. The data from this study seems promising and worthy to be investigated in depth. ${ }^{67)}$ A preliminary randomized double-blind placebo-controlled study in healthy human suggests the effectiveness of prodrug LY544344 strategy in reducing panic anxiety induced by cholecystokinin tetrapeptide (CCK-4) injection. The validity of CCK-4 as panicogenic-challenge is not clear thus warrants further clinical trials with well-validated technique to induce panic attack to test the anti-panic properties of LY544344. ${ }^{68)}$ In summary, type II mGluR2/3 agonist may offer some advantages in which no sedation and dependency liabilities as seen in benzodiazepines and no loss of libido as seen in antidepressants.

\section{Levetiracetam}

Levetiracetam is an antiepileptic drug approved by the United States Food and Drug Administration in 1999. ${ }^{69}$ The exact mechanism of action of this drug is unclear but it seems to modulate high-voltage, $\mathrm{N}$-type, voltage-dependent calcium channels and potassium currents, while the selective potentiation of GABAA-mediated responses is controversial. However, recently it has been suggested that the main mechanism of action is in relation to modulation of synaptic vesicle protein $2 \mathrm{~A}$ involved in vesicle exocytosis. ${ }^{70)}$ Previous study suggested that this drug possesses potential therapeutic benefits in the patients with anxiety spectrum disorders. ${ }^{71)}$ Another previous study showed that PD patients administered with levetiracetam at the dosage of $250 \mathrm{mg}$ twice daily has a clinically significant improvement with minimal adverse effects. The common adverse effects observed were sedation, headache, and irritability. ${ }^{72)}$

\section{LIMITATIONS}

Although the credibility of the mentioned clinical studies are subjected to criticism because of the potential for residual confounding factors or bias due to unmeasured variables, these studies are important before embarking on further trials with larger sample size (to detect subtle differences) and inclusion of placebo control group (to clarify specific effect magnitude of such compounds as compared to placebo) as well as active comparators group (to elucidate whether these novel compounds are as effective and well tolerated as the standard drug). These studies should not be discouraging but rather indicate the need for ample support via strong randomized controlled trials to further confirm their true efficacy. Apart from their effectiveness, their tolerability should be well reported, showing that they meet the standard requirement as an alternative drug for PD. 


\section{CONCLUSION}

Positive preliminary evidences suggest that new compounds such as SNRI duloxetine, NRI reboxetine, NaSSA mirtazapine, SARI nefazodone, atypical antipsychoticrisperidone and inositol have high efficacy and potency for treatment-resistant patients with PD. Furthermore, all drugs included in this review were generally well tolerated as compared to SSRI and benzodiazepines, indicating their potential therapeutic usefulness for ambivalent and hypervigilance patients.

\section{REFERENCES}

1. Kessler RC, Berglund P, Demler O, Jin R, Merikangas KR, Walters EE. Lifetime prevalence and age-of-onset distributions of DSM-IV disorders in the National Comorbidity Survey Replication. Arch Gen Psychiatry 2005;62:593-602.

2. Kessler RC, Chiu WT, Demler O, Walters EE. Prevalence, severity, and comorbidity of twelve-month DSM-IV disorders in the National Comorbidity Survey Replication (NCS-R). Arch Gen Psychiatry 2005;62:617-627.

3. King M, Nazareth I, Levy G, Walker C, Morris R, Weich S, et al. Prevalence of common mental disorders in general practice attendees across Europe. Br J Psychiatry 2008;192:362367.

4. Marchesi C. Pharmacological management of panic disorder. Neuropsychiatr Dis Treat 2008;4:93-106.

5. Masi G, Favilla L, Mucci M, Millepiedi S. Panic disorder in clinically referred children and adolescents. Child Psychiatry Hum Dev 2000;31:139-151.

6. American Psychiatric Association. Diagnostic and statistical manual of mental disorders: DSM-IV-TR. 4th ed. Washington, DC:American Psychiatric Association; 2000.

7. Kessler RC, Chiu WT, Jin R, Ruscio AM, Shear K, Walters EE. The epidemiology of panic attacks, panic disorder, and agoraphobia in the National Comorbidity Survey Replication. Arch Gen Psychiatry 2006; 63:415-424.

8. Gorman JM, Kent JM, Sullivan GM, Coplan JD. Neuroanatomical hypothesis of panic disorder, revised. Am I Psychiatry 2000; 157:493-505.

9. Freire RC, Hallak JE, Crippa JA, Nardi AE. New treatment options for panic disorder: clinical trials from 2000 to 2010. Expert Opin Pharmacother 2011;12:1419-1428.

10. Perna G, Guerriero G, Caldirola D. Emerging drugs for panic disorder. Expert Opin Emerg Drugs 2011;16:631-645.

11. Nardi AE, Freire RC, Zin WA. Panic disorder and control of breathing. Respir Physiol Neurobiol 2009;167:133-143.

12. Gorman JM, Docherty JP. A hypothesized role for dendritic remodeling in the etiology of mood and anxiety disorders. J Neuropsychiatry Clin Neurosci 2010;22:256-264.

13. Klein DF. False suffocation alarms, spontaneous panics, and related conditions. An integrative hypothesis. Arch Gen Psychiatry 1993;50:306-317.

14. Esquivel G, Schruers KR, Maddock RJ, Colasanti A, Griez EJ. Acids in the brain: a factor in panic? J Psychopharmacol 2010; 24:639-647.

15. Austin D, Blashki G, Barton D, Klein B. Managing panic disorder in general practice. Aust Fam Physician 2005;34:563571.

16. Marchesi C, De Panfilis C, Cantoni A, Fontò S, Giannelli MR, Maggini C. Personality disorders and response to medication treatment in panic disorder: a 1-year naturalistic study. Prog NeuroPsychopharmacol Biol Psychiatry 2006;30:1240-1245.

17. Bakker A, van Balkom AJ, Stein DJ. Evidence-based pharmacotherapy of panic disorder. Int I Neuropsychopharmacol 2005;8:473-482.

18. Roy-Byrne PP, Craske MG, Stein MB. Panic disorder. Lancet 2006;368:1023-1032.

19. Batelaan NM, Van Balkom AJ, Stein DJ. Evidence-based pharmacotherapy of panic disorder: an update. Int J Neuropsychopharmacol 2012;15:403-415.

20. Bystritsky A, Kerwin L, Niv N, Natoli JL, Abrahami N, Klap R, et al. Clinical and subthreshold panic disorder. Depress Anxiety 2010;27:381-389.

21. Kroenke K. Patients presenting with somatic complaints: epidemiology, psychiatric comorbidity and management. Int J Methods Psychiatr Res 2003;12:34-43.

22. Starcevic V. Treatment of panic disorder: recent developments and current status. Expert Rev Neurother 2008;8:12191232.

23. National Institute for Health and Clinical Excellence (NICE), National Collaborating Centre for Mental Health, National Collaborating Centre for Primary Care. Generalised anxiety disorder and panic disorder (with or without agoraphobia) in adults: management in primary, secondary and community care [CG113]. London:NICE;2011.

24. Mitte K. A meta-analysis of the efficacy of psycho- and pharmacotherapy in panic disorder with and without agoraphobia. J Affect Disord 2005;88:27-45.

25. Imai H, Tajika A, Chen P, Pompoli A, Furukawa TA. Psychological therapies versus pharmacological interventions for panic disorder with or without agoraphobia in adults. Cochrane Database Syst Rev 2016;10:CD011170.

26. Gould RA, Ott MW, Pollack MH. A meta-analysis of treatment outcome for panic disorder. Clin Psychol Rev 1995;15:819844.

27. Bighelli I, Trespidi C, Castellazzi M, Cipriani A, Furukawa TA, Girlanda F, et al. Antidepressants and benzodiazepines for panic disorder in adults. Cochrane Database Syst Rev 2016;9: CD011567.

28. Otto MW, Tuby KS, Gould RA, McLean RY, Pollack MH. An effect-size analysis of the relative efficacy and tolerability of serotonin selective reuptake inhibitors for panic disorder. Am J Psychiatry 2001;158:1989-1992. 
29. Bakker A, van Balkom AJ, Spinhoven P. SSRIs vs. TCAs in the treatment of panic disorder: a meta-analysis. Acta Psychiatr Scand 2002; 106:163-167.

30. Andrisano C, Chiesa A, Serretti A. Newer antidepressants and panic disorder: a meta-analysis. Int Clin Psychopharmacol 2013;28:33-45.

31. American Psychiatric Association. Practice guideline for the treatment of patients with panic disorder. 2nd ed. Washington, D.C.:American Psychiatric Association;2009.

32. Bandelow B, Zohar J, Hollander E, Kasper S, Möller HJ; WFSBP Task Force on Treatment Guidelines for Anxiety, Obsessive-Compulsive and Post-Traumatic Stress Disoders, Zohar J, et al. World Federation of Societies of Biological Psychiatry (WFSBP) guidelines for the pharmacological treatment of anxiety, obsessive-compulsive and post-traumatic stress disorders - first revision. World J Biol Psychiatry 2008;9: 248-312.

33. Serretti A, Chiesa A, Calati R, Perna G, Bellodi L, De Ronchi D. Novel antidepressants and panic disorder: evidence beyond current guidelines. Neuropsychobiology 2011;63:1-7.

34. Freire RC, Machado S, Arias-Carrión O, Nardi AE. Current pharmacological interventions in panic disorder. CNS Neurol Disord Drug Targets 2014;13:1057-1065.

35. Susman J, Klee B. The role of high-potency benzodiazepines in the treatment of panic disorder. Prim Care Companion J Clin Psychiatry 2005; 7:5-11.

36. Ferguson JM. SSRI antidepressant medications: adverse effects and tolerability. Prim Care Companion J Clin Psychiatry 2001;3:22-27.

37. Serretti A. The present and future of precision medicine in psychiatry: focus on clinical psychopharmacology of antidepressants. Clin Psychopharmacol Neurosci 2018;16:1-6.

38. Perna G, Schruers K, Alciati A, Caldirola D. Novel investigational therapeutics for panic disorder. Expert Opin Investig Drugs 2015;24:491-505.

39. Gupta S, Nihalani N, Masand P. Duloxetine: review of its pharmacology, and therapeutic use in depression and other psychiatric disorders. Ann Clin Psychiatry 2007; 19:125-132.

40. Simon NM, Kaufman RE, Hoge EA, Worthington JJ, Herlands NN, Owens ME, et al. Open-label support for duloxetine for the treatment of panic disorder. CNS Neurosci Ther 2009;15: 19-23.

41. Anttila SA, Leinonen EV. A review of the pharmacological and clinical profile of mirtazapine. CNS Drug Rev 2001;7:249264.

42. Carpenter LL, Leon Z, Yasmin S, Price LH. Clinical experience with mirtazapine in the treatment of panic disorder. Ann Clin Psychiatry 1999;11:81-86.

43. Boshuisen ML, Slaap BR, Vester-Blokland ED, den Boer JA. The effect of mirtazapine in panic disorder: an open label pilot study with a single-blind placebo run-in period. Int Clin Psychopharmacol 2001;16:363-368.

44. Carli V, Sarchiapone M, Camardese G, Romano L, DeRisio S.
Mirtazapine in the treatment of panic disorder. Arch Gen Psychiatry 2002;59:661-662.

45. Sarchiapone M, Amore M, De Risio S, Carli V, Faia V, Poterzio $\mathrm{F}$, et al. Mirtazapine in the treatment of panic disorder: an open-label trial. Int Clin Psychopharmacol 2003;18:35-38.

46. Ribeiro L, Busnello JV, Kauer-Sant'Anna M, Madruga M, Quevedo J, Busnello EA, et al. Mirtazapine versus fluoxetine in the treatment of panic disorder. Braz J Med Biol Res 2001; 34:1303-1307.

47. Montañes-Rada F, Bilbao-Garay J, de Lucas-Taracena MT, Ortiz-Ortiz ME. Venlafaxine, serotonin syndrome, and differential diagnoses. J Clin Psychopharmacol 2005;25:101-102.

48. Wong EH, Sonders MS, Amara SG, Tinholt PM, Piercey MF, Hoffmann WP, et al. Reboxetine: a pharmacologically potent, selective, and specific norepinephrine reuptake inhibitor. Biol Psychiatry 2000;47:818-829.

49. Dannon PN, Iancu I, Grunhaus L. The efficacy of reboxetine in the treatment-refractory patients with panic disorder: an open label study. Hum Psychopharmacol 2002;17:329-333.

50. Versiani M, Cassano G, Perugi G, Benedetti A, Mastalli L, Nardi A, et al. Reboxetine, a selective norepinephrine reuptake inhibitor, is an effective and well-tolerated treatment for panic disorder. J Clin Psychiatry 2002;63:31-37.

51. Seedat S, van Rheede van Oudtshoorn E, Muller JE, Mohr N, Stein DJ. Reboxetine and citalopram in panic disorder: a single-blind, cross-over, flexible-dose pilot study. Int Clin Psychopharmacol 2003;18:279-284.

52. Bertani A, Perna G, Migliarese G, Di Pasquale D, Cucchi M, Caldirola D, et al. Comparison of the treatment with paroxetine and reboxetine in panic disorder: a randomized, single-blind study. Pharmacopsychiatry 2004;37:206-210.

53. Davis R, Whittington R, Bryson HM. Nefazodone. A review of its pharmacology and clinical efficacy in the management of major depression. Drugs 1997;53:608-636.

54. DeMartinis NA, Schweizer E, Rickels K. An open-label trial of nefazodone in high comorbidity panic disorder. I Clin Psychiatry 1996;57:245-248.

55. Bystritsky A, Rosen R, Suri R, Vapnik T. Pilot open-label study of nefazodone in panic disorder. Depress Anxiety 1999;10: 137-139.

56. Papp LA, Coplan JD, Martinez JM, de Jesus M, Gorman JM. Efficacy of open-label nefazodone treatment in patients with panic disorder. J Clin Psychopharmacol 2000;20:544-546.

57. Grant S, Fitton A. Risperidone. A review of its pharmacology and therapeutic potential in the treatment of schizophrenia. Drugs 1994;48:253-273.

58. Prosser JM, Yard S, Steele A, Cohen LJ, Galynker II. A comparison of low-dose risperidone to paroxetine in the treatment of panic attacks: a randomized, single-blind study. BMC Psychiatry 2009;9:25.

59. Kim H, McGrath BM, Silverstone PH. A review of the possible relevance of inositol and the phosphatidylinositol second messenger system (Pl-cycle) to psychiatric disorders--focus on 
magnetic resonance spectroscopy (MRS) studies. Hum Psychopharmacol 2005;20:309-326.

60. Benjamin J, Levine J, Fux M, Aviv A, Levy D, Belmaker RH. Double-blind, placebo-controlled, crossover trial of inositol treatment for panic disorder. Am J Psychiatry 1995; 152:10841086.

61. Palatnik A, Frolov K, Fux M, Benjamin J. Double-blind, controlled, crossover trial of inositol versus fluvoxamine for the treatment of panic disorder. I Clin Psychopharmacol 2001;21:335-339.

62. Shekhar A, Keim SR. LY354740, a potent group I/ metabotropic g/utamate receptor agonist prevents lactate-induced panic-like response in panic-prone rats. Neuropharmacology 2000;39:1139-1146.

63. Javitt DC. Glutamate as a therapeutic target in psychiatric disorders. Mol Psychiatry 2004;9:984-997, 979.

64. Grillon C, Cordova J, Levine LR, Morgan CA 3rd. Anxiolytic effects of a novel group /I metabotropic g/utamate receptor agonist (LY354740) in the fear-potentiated startle paradigm in humans. Psychopharmacology (Berl) 2003;168:446-454.

65. Schoepp DD, Wright RA, Levine LR, Gaydos B, Potter WZ. $\angle Y 354740$, an mGlu2/3 receptor agonist as a novel approach to treat anxiety/stress. Stress 2003;6:189-197.

66. Bergink V, Westenberg HG. Metabotropic g/utamate // re- ceptor agonists in panic disorder: a double blind clinical trial with LY354740. Int Clin Psychopharmacol 2005;20:291293.

67. Rorick-Kehn LM, Perkins EJ, Knitowski KM, Hart JC, Johnson BG, Schoepp DD, et al. Improved bioavailability of the $m G / u 2 / 3$ receptor agonist $L Y 354740$ using a prodrug strategy: in vivo pharmacology of LY544344. I Pharmacol Exp Ther 2006;316:905-913.

68. Kellner M, Muhtz C, Stark K, Yassouridis A, Arlt J, Wiedemann K. Effects of a metabotropic glutamate(2/3) receptor agonist (LY544344/LY354740) on panic anxiety induced by cholecystokinin tetrapeptide in healthy humans: preliminary results. Psychopharmacology (Berl) 2005;179:310-315.

69. Crepeau AZ, Treiman DM. Levetiracetam: a comprehensive review. Expert Rev Neurother 2010;10:159-171.

70. Mula M, Pini S, Cassano GB. The role of anticonvulsant drugs in anxiety disorders: a critical review of the evidence. J Clin Psychopharmacol 2007;27:263-272.

71. Lamberty Y, Falter U, Gower AJ, Klitgaard H. Anxiolytic profile of the antiepileptic drug levetiracetam in the Vogel conflict test in the rat. Eur I Pharmacol 2003;469:97-102.

72. Papp LA. Safety and efficacy of levetiracetam for patients with panic disorder: results of an open-label, fixed-flexible dose study. J Clin Psychiatry 2006;67:1573-1576. 